\title{
MODEL KEPERILAKUAN ATAS KONSUMSI PRODUK BAJAKAN
}

\author{
Nur Achmad \\ Fakultas Ekonomi dan Bisnis, Universitas Muhammadyah Surakarta \\ nur.achmad@ums.ac.id \\ Edy Purwo Saputro \\ Fakultas Ekonomi dan Bisnis, Universitas Muhammadyah Surakarta
}

\begin{abstract}
Behavioral research on the case of mp3 music downloading is an interesting study since this case seems correlated to many occasions. An empiric study results that this kind of behavior happens not merely in the developed industrial countries but also in developing countries. On the one side, the results from empirical research indicates various factors, and on the other side there is research gap suitable for the observation settings in this research. This research aims to find out the behavioral models on the consumption of piracy products, especially concerning on the mp3 music downloading. This research involves a number of 100 students for the research samples, and utilizes structural analysis supported by maximum likelihood method. Indirectly, the result is reinforcing the arguments related to the various factors which is enforcing mp3 music downloading behaviors, although from the other point of view, this research found the importance of rational model on the mp3 music downloading behavior. The limitedness on this research will become a suggestion for the future research to the variable explorations and observation settings in order to support the generalization process of the results in accordance with behavioral research.
\end{abstract}

Keywords: behavioral, mp3, piracy products

\begin{abstract}
ABSTRAK
Penelitian keperilakuan berkenaan dengan kasus pengunduhan file musik dalam format mp3 merupakan sebuah studi yang menarik oleh karena hal ini tampaknya berkorelasi dengan berbagai kegiatan. Hasil-hasil studi empirik menunjukkan bahwa perilaku semacam itu terjadi bukan hanya di negara-negara maju tetapi juga di negara-negara sedang berkembang. Di satu sisi, hasil-hasil penelitian empiris menunjukkan terdapat berbagai faktor, namun di sisi lain masih terdapat kesenjangan penelitian yang dapat diobservasi. Penelitian ini bertujuan untuk mengetahui perilaku pada konsumsi produk bajakan, terutama menyangkut pada pengunduhan file musik dalam format mp3. Penelitian ini melibatkan 100 siswa sebagai sampel penelitian dan menggunakan analisis struktural yang didukung dengan metode maximum likelihood. Secara tidak langsung, hasil penelitian ini memperkuat argumen terkait dengan berbagai faktor yang mendorong perilaku untuk mengunduh file musik dalam format mp3, meskipun dari sudut pandang lain, penelitian ini menemukan pentingnya model rasional pada perilaku mengunduh file
\end{abstract}


musik dalam format mp3. Keterbatasan pada penelitian ini menjadi saran untuk penelitian masa depan, yakni berkaitan dengan eksplorasi variabel dan pengaturan observasi dalam rangka mendukung proses generalisasi penelitian keperilakuan.

Kata kunci: keperilakuan, mp3, produk-produk bajakan

\section{PENDAHULUAN}

Perkembangan teknologi dan internet secara tidak tidak langsung berpengaruh terhadap perilaku konsumen yaitu di satu sisi hal ini berpengaruh positif, tapi di sisi lain juga menimbulkan pengaruh negatif (Anaza \& Zhao 2013; Colla \& Lapoule 2012). Fakta pengaruh positif misal terlihat semakin tingginya transaksi $e$-commerce, terutama melalui transaksi online. Bahkan, ini menjadi peluang bisnis yang menjanjikan. Kasus di Indonesia juga menunjukan trend belanja online kian meningkat. Hal ini didukung data Asosiasi Penyelengara Jasa Internet Indonesia, Emarketer dan Nielsen Global Survey 2014 bahwa pengguna internet tahun 2014 yaitu 107 juta, pengguna smartphone tahun 2014 yaitu 38,3 juta dan prediksi tahun 2018 menjadi 103 juta, perangkat belanja online tahun 2014 mayoritas dari ponsel (61\%), komputer (58\%) dan tablet (39\%). Selain itu, data di tahun 2014 menunjukan top produk belanja online adalah tiket pesawat (55\%), hotel (46\%), e-books (40\%), fashion (37\%) dan event (34\%).

Fakta pengaruh positif dari perkembangan Internet ternyata juga diikuti dampak negatif. Fakta tentang dampak negatif dari perkembangan teknologi dan Internet adalah semakin terbukanya peluang melakukan pembajakan terhadap berbagai bentuk produk atau karya cipta. Selain itu, semakin murahnya hardware baik dalam bentuk komputer atau smartphone juga didukung dengan tarif internet yang semakin murah dan juga akses internet yang semakin cepat, mudah dan murah secara tidak langsung memberikan aspek peluang terhadap berbagai bentuk kejahatan berbasis kegiatan online. Dari berbagai hal yang memicu kerawanan terhadap tindakan kejahatan tersebut salah satunya yang saat ini cenderung meningkat yaitu pembajakan, tidak hanya pada kasus musik berbasis mp3 tapi juga film dan karya-karya lain yang bisa diakses melalui internet (Phau et al., 2014; Beekhuyzen, Von Hellens, \& Nielsen 2011; Nill \& Shultz 2009; Lysonski \& Durvasula 2008).

Persoalan tentang pembajakan berbasis layanan online melalui internet terkait dengan tiga aspek yaitu pertama: aspek ekonomi. Pembajakan merupakan suatu tindakan yang berusaha untuk mendapatkan keuntungan karena tidak melalui transaksi yang semestinya dilakukan. Artinya, ada pihak yang diuntungkan yaitu konsumen yang mengunduh atau membajak dan di sisi lain ada pihak yang dirugikan karena hak-haknya tidak dibayarkan. Kedua aspek sosial yaitu terkait dengan norma perilaku bahwa saat ini mengunduh atau membajak secara online dianggap sebagai sesuatu yang wajar sehingga semua orang bisa melakukannya dengan mudah dan yang ketiga adalah aspek hukum yaitu regulasi yang berlaku tidak mampu mereduksi perilaku mengunduh atau membajak sehingga kecenderungan terjadinya perilaku mengunduh atau membajak semakin tinggi. 
Persoalan produk bajakan merupakan salah satu fenomena yang tidak hanya terjadi di negara miskin berkembang, tetapi hal ini juga banyak terjadi di negara industri maju (Phau et al., 2014; Sirkeci \& Magnúsdóttir 2011; Chu \& Lu 2007; Cheung \& Prendergast 2006). Fakta ini dipicu banyak faktor, baik dari dalam internal individu dan juga faktor eksternal. Faktor internal misalnya karena pengaruh perbedaan harga antara produk original dengan produk bajakan yang relatif tinggi dan kualitas produk yang tidak jauh berbeda antara yang versi original vs yang bajakan (Cronan \& Al-Rafee 2008). Faktor eksternal misal karena faktor tidak adanya penerapan sanksi, baik sanksi hukum atau sanksi normal sosial terhadap konsumen pengguna produk bajakan (Doherty 2006; Dong et al., 2002). Bahkan kasus di negara miskin berkembang fenomena konsumsi produk bajakan seolah menjadi ciri dalam kehidupan kesehariannya karena telah jamak dilakukan (Lysonski \& Durvasula 2008; Kwong et al., 2003).

Fakta perilaku konsumsi produk bajakan tidak hanya terjadi di produk-produk yang berpengaruh terhadap kepercayaan diri atau aktualisasi diri penggunanya, tapi fakta konsumsi produk bajakan juga marak pada industri music (Phau et al., 2014; Vida et al., 2012; Williams, Nicholas, \& Rowlands 2010). Terkait hal ini, konsumsi mp3 bajakan ternyata juga semakin tinggi. Oleh karena itu, beralasan jika beberapa musisi melakukan kampanye anti produk bajakan. Hal ini dilakukan karena produk bajakan mp3 yang diunduh oleh konsumen memberikan dampak negatif terhadap negara melalui rendahnya penerimaan pajak dan juga perkembangan industri musik rekaman itu sendiri karena royalti tidak dibayarkan (Beekhuyzen, Von Hellens, \& Nielsen 2011; Lewis, Graham, \& Hardaker 2005; Graham et al., 2004; Mathews 2001). Oleh karena itu, mata rantai dari dampak pembajakan tidak hanya bisa dikalkulasi dari produsen tapi juga bagi negara. Hal ini mengindikasikan bahwa dampak pembajakan tidak hanya mengacu jangka pendek, tapi juga jangka panjang.

Dualisme dari konsumsi produk bajakan untuk kasus mengunduh mp3 memang menjadi persoalan serius, tidak hanya di negara industri maju, tapi juga di negara miskin berkembang, meskipun di sisi lain realitas ini tidak bisa dicegah karena ada banyak nilai kepentingan yang terlibat (Kwong et al., 2003; Cheung \& Prendergast 2006; Lysonski \& Durvasula 2008; Sirkeci \& Magnúsdóttir 2011; Phau et al., 2014). Oleh karena itu, riset model keperilakuan terhadap konsumsi produk bajakan untuk kasus mengunduh mp3 menarik dilakukan dan tujuan penelitian ini untuk mengetahui model keperilakuan tersebut mengacu tatanan (setting) amatan di Solo.

Pertimbangan pemilihan tatanan amatan di Solo karena mewakili karakteristik dari populasi yaitu masyarakat yang familier dengan era online dan juga berkebutuhan terhadap musik sehingga hal ini diidentifikasi dengan kelompok mahasiswa. Di sisi lain, Solo memiliki sejumlah perguruan tinggi dan keberadaan UMS merupakan salah satu perguruan tinggi swasta dan perguruan tinggi Muhammadiyah terbesar sehingga alasan pemilihan sampel dari FEB UMS diharapkan mewakili karakteristik populasi tersebut. 
Urgensi penelitian tentang produk bajakan tidak hanya mengacu kepada kajian dari aspek keperilakuan, tetapi juga aspek budaya dan sikap individu dalam memahami fenomena sosial yang berkembang. Oleh karena itu, manfaat penelitian ini adalah mendukung konsep teoritis tentang keperilakuan yang cenderung terus berkembang dengan berbagai konsekuensi, terutama untuk kasus konsumsi produk bajakan. Memberikan edukasi dampak internet yaitu tidak saja dari kepentingan konsumen, tapi juga produsen dan pemasar terutama terkait dengan perkembangan e-marketer dan $e$ lifestyle di era global information society yang mendukung transaksi online. Memberikan pemahaman tentang faktor pentingnya kalkulasi kerugian dari perilaku mengunduh musik format mp3, meskipun di sisi lain fenomena ini justru dianggap sebagai perilaku yang legal bagi sebagian besar konsumen, serta manfaat praktis bagi semua pihak yang berkompeten dengan perkembangan industri musik, baik berbasis online ataupun nononline karena realita ancaman pembajakan bisa dilakukan oleh siapa saja dan dimana saja.

\section{KAJIAN PUSTAKA DAN PERUMUSAN HIPOTESIS}

\section{Perilaku Konsumen}

Perilaku konsumen merupakan tindakan yang memungkinkan individu untuk melakukan pilihan dari berbagai alternatif untuk memenuhi kebutuhan. Oleh karena itu individu akan selektif sebelum memutuskan perilaku konsumsinya. Berbagai alternatif yang menjadi pertimbangan perilaku konsumen misal aspek harga, kualitas dan merek sehingga semua pertimbangan tersebut menjadi argumen untuk menentukan sikap. Hal ini menegaskan bahwa sikap positif individu akan berpengaruh terhadap perilaku untuk menentukan pilihan dan tindakan sehingga ini memperkuat argumen bahwa riset tentang keperilakuan cenderung mengacu kepada sikap dan niat individu. Terkait hal ini, di era global information society yang didukung perkembangan internet dan tarif internet yang semakin murah serta perkembangan smartphone gadget maka pilihan untuk pemuasan kebutuhan konsumen cenderung semakin terbuka, termasuk juga dalam aspek konsumsi terhadap produk music (Fullerton \& Schmidt 2005).

Perilaku konsumen terhadap berbagai produk musik mengalami pergeseran seiring dengan perkembangan teknologi mulai dari piringan hitam, pita kaset, VCD, CD, DVD dan format mp3. Konsekuensi dari perubahan dan perkembangan tersebut secara tidak langsung juga berpengaruh terhadap niat beli dan sikap individu dalam perilaku konsumen. Konsumsi terhadap musik cenderung mengalami perkembangan pesat dan industri musik merupakan salah satu industri yang memberikan kontribusi bagi belanja konsumen. Hal ini tidak hanya terjadi di negara industri maju, tapi juga di negara miskin berkembang, termasuk yang terjadi di Indonesia. Oleh karena itu, perkembangan industri musik memberikan sisi manfaat dari aspek pendapatan pajak dan royalti serta manfaat bagi perkembangan di dunia hiburan. Konsekuensi dari perkembangan industri musik juga berpengaruh terhadap perilaku konsumen. Hal ini terutama dipicu karakteristik dan realitas strata ekonomi yang cenderung beragam. Fakta ini menegaskan bahwa perilaku 
konsumen tidak bisa terlepas dari segmentasi untuk semua target pasar. Artinya, esensi penelitian ini terkait kesadaran kolektif terhadap konsumsi dari produk bajakan.

Kesadaran kolektif untuk mereduksi perilaku konsumsi bajakan untuk kasus mengunduh mp3 tidak mudah karena terkait dengan budaya dan minimnya penegakan hukum. Oleh karena itu, hasil penelitian ini tidak hanya memberikan harapan terhadap pemahaman konsep dan teoritis tentang keperilakuan terhadap konsumsi untuk produk bajakan, tetapi juga pemahaman tentang fenomena dilema industri musik yaitu di satu sisi harus terus berkarya sementara di sisi lain dihadapkan pada realitas pembajakan yang meniadakan pendapatan royalti bagi musisi dan pajak bagi negara.

\section{Era Online vs Industri Musik}

Trend belanja online sebagai bagian dari fenomena global information society saat ini cenderung semakin berkembang. Hal ini tidak hanya terjadi pada transaksi untuk e-commerce, tetapi juga niat beli terhadap musik di dunia online (Tewell 2010; Chu \& Lu 2007; Walsh et al., 2003; Wilcox 2003). Kondisi ini juga semakin didukung oleh smartphone gadget yang mampu untuk mengakses internet sebagai bagian dari model dukungan mobilitas individu. Di satu sisi, mobilitas itu sendiri tidak bisa terlepas dari tuntutan hiburan dan di sisi lain musik di internet mampu memberikan fasilitas hiburan tersebut karena mampu diakses dimana saja dan kapan saja secara real time online. Oleh karena itu, interaksi antara perkembangan internet dan musik di era global information society cenderung positif, meski di sisi lain ada risiko yang tidak bisa diantisipasi dan hal ini adalah konsekuensi dari perkembangan teknologi.

Sinergi antara perkembangan teknologi, internet dan industri musik secara tidak langsung memicu dikotomi. Di satu sisi perkembangan industri musik tidak bisa terlepas dari perubahan perilaku konsumen sebagai bagian dari perubahan pemasaran, sementara di sisi lain kebutuhan terhadap informasi dan hiburan juga semakin tinggi. Hal ini terkait dengan perubahan perilaku konsumen dan reealitas model $e$-marketing yang cenderung mengalami perkembangan pesat seiring dengan kemudahan dalam transaksi online yang diukung oleh fasilitas pembiayaan secara online (Amberg \& Schröder 2007; Brodie et al., 2007). Oleh karena fenomena pembajakan lagu format mp3 menarik dikaji karena ada banyak kepentingan yang terlibat dari kasus ini.

\section{Riset Terkait Konsumsi Produk Bajakan}

Produk bajakan merupakan fenomena dalam model keperilakuan dan hal ini terjadi karena perbedaan persepsi antara harga dan kualitas menurut konsumen. Hal ini menegaskan segmentasi pasar berdasar daya beli yang pada dasarnya merupakan sesuatu yang klasik di bidang pemasaran. Disparitas harga inilah memicu perilaku pembajakan produk dan niat mengkonsumsi produk bajakan. Beberapa hasil riset menguatkan fakta trend perilaku individu terhadap produk bajakan (Phau et al., 2014; Phau \& Liang 2012; Vida et al., 2012; Beekhuyzen, Von Hellens, \& Nielsen 2011; Sirkeci \& Magnúsdóttir 2011; Williams, Nicholas, \& Rowlands 2010; Lysonski \& Durvasula 2008; Chu \& Lu 2007; Cronan \& Al-Rafee 2008; Cheung \& Prendergast 2006). Ironisnya, fenomena 
pembajakan ini tidak hanya terjadi di negara miskin berkembang tetapi realita ini juga terjadi di negara industri maju yang diyakini memiliki tingkat kesadaran terhadap hak cipta dan royalti relatif lebih tinggi (Williams, Nicholas, \& Rowlands 2010; Vida et al., 2012). Oleh karena itu, fenomena ini menjadi kajian yang menarik untuk diteliti.

Hasil riset Chu dan Lu (2007) menegaskan bahwa 70 persen masyarakat di Asia yang memiliki lagu format mp3 diperoleh dengan cara mengunduh secara ilegal dan dari jumlah itu ternyata 80 persen diantaranya adalah berasal dari daerah Cina, Taiwan dan Hongkong. Kekhawatiran perkembangan internet bagi industri musik sebenarnya telah diantisipasi Walsh et al. (2003) yang dalam risetnya menegaskan fakta perkembangan dan teknologi rekaman memberikan peluang setiap individu untuk melakukan tindakan pembajakan secara mandiri. Oleh karena itu, beralasan jika fenomena ini dipengaruhi dua faktor yaitu karakteristik individu dan variabel situasional. Artinya, ketika perilaku mengunduh mp3 secara ilegal di internet dianggap sebagai kewajaran maka perilaku ini menjadi jamak dilakukan di semua level usia konsumen, tanpa terkecuali.

Fakta tidak adanya sanksi sosial sebagai variabel situasional pada kasus unduh mp3 melalui internet kemudian justru berkembang di industri lainnya. Hal ini diperkuat oleh temuan hasil riset Phau dan Liang (2012) untuk kasus mengunduh video games yang justru dilakukan mayoritas mahasiswa di Australia. Temuan ini memberi gambaran bahwa kelompok generasi muda yang familier dengan internet dan dunia online sangat terbuka kesempatannya mengunduh berbagai sajian informasi dan hiburan di internet, termasuk musik format mp3 dan juga video games. Temuan ini jua diperkuat hasil riset Phau et al. (2014) bahwa mahasiswa di Australia juga mengunduh film melalui internet secara ilegal. Fenomena ini secara tidak langsung justru menegaskan bahwa kemudahan akses memberikan peluang sangat terbuka di internet dan dunia online untuk mengunduh secara ilegal. Jika tidak ada sanksi tegas maka hal ini akan berkembang menjadi suatu kebiasaan bagi konsumen.

Urgensi terhadap sanksi dan fenomena tentang kewajaran yang justru semakin berkembang maka beralasan jika Vida et al. (2012) telah memprediksi adanya ancaman rasionalisasi perilaku mengunduh mp3 bajakan dari internet. Oleh karena itu wajar jika kebiasaan mengunduh mp3 secara ilegal melalui internet jamak dilakukan. Konsekuensi dari hal ini memicu kerugian besar. Data dari BASCAP (2011 dikutip dari Vida et al., (2012)) menunjukan kerugian dari perilaku ini mencapai sekitar US\$30-75 Miliar dan diprediksi menjadi US\$240 Miliar pada tahun 2015 ketika hal ini berkembang karena dianggap wajar atau legal. Fakta ini menguatkan temuan riset tersebut bahwa perilaku mengunduh mp3 dan lainnya di internet dianggap sebagai perilaku rasional dan legal karena jamak semua orang melakukannya dimana saja dan kapan saja. Fakta ini adalah rasionalisasi yang cenderung salah kaprah. Oleh karena itu, riset keperilakuan tentang hal ini menjadi sangat menarik diteliti karena terkait dengan perilaku sosial.

Fenomena ancaman serius dari pembajakan musik format mp3 melalui internet ternyata tidak hanya terjadi di negara miskin berkembang, tetapi hal ini juga terjadi di 
negara industri maju (Williams et al., 2010; Vida et al., 2012). Bahkan, mahasiswa di negara industri maju yang diyakini telah memiliki pengetahun lebih baik tentang aspek legalitas dan hak cipta ternyata juga tidak bisa mengindar dari godaan untuk melakukan pembajakan musik format mp3 melalui internet. Paling tidak, ini sesuai dengan temuan riset Lysonski dan Durvasula (2008) untuk kasus mahasiswa di Amerika. Ironisnya, temuan ini menegaskan bahwa mengunduh musik mp3 melalui internet bukan dianggap sebagai etika yang salah. Oleh karena itu, beralasan jika rekomendasi temuan riset ini menegaskan pentingnya sanksi moral dan sosial yang harus dilakukan secara bersamaan.

Urgensi sanksi moral dan sanksi sosial bukanlah yang persoalan mudah karena pembajakan sudah berkembang menjadi industri tersendiri. Hasil riset dari Cheung dan Prendergast (2006) menegaskan kasus di Cina industri bajakan cenderung berkembang dan tidak hanya produk tapi juga logo dan brand name sehingga memerangi pembajakan sangatlah penting dan sama pentingnya dengan proses research and development untuk penciptaan dan inovasi produk. Ironisnya kampanye memerangi pembajakan tidak bisa tuntas karena fasilitas untuk mengunduh melalui internet tersaji dengan mudah dan murah. Fakta inilah yang menjadi argumen pentingnya riset perilaku konsumen terkait dengan pembajakan musik format mp3 melalui internet karena fenomena ini menjadi sesuatu yang gamang untuk dituntaskan.

\section{Perumusan Hipotesis}

\section{Hubungan Perceived Usefulness dengan Perceived Risk dan Social Habit}

Perumusan hipotesis dan model dari penelitian ini mengacu hasil sejumlah riset empiris sebelumnya. Meskipun demikian, setting amatan dari penelitian ini terfokus pada kasus produk bajakan mp3 dengan responden yaitu kelompok generasi muda yang diwakili oleh mahasiswa. Keterlibatan mahasiswa sebagai responden dalam riset produk bajakan telah banyak dilakukan (Phau et al., 2014; Phau \& Liang 2012; Lysonski \& Durvasula 2008). Pengembangan hipotesis dalam penelitian ini mengacu sejumlah hasil riset empiris (Phau et al., 2014; Phau \& Liang 2012; Vida et al., 2012; Beekhuyzen et al., 2011; Sirkeci \& Magnúsdóttir 2011; Williams et al., 2010; Lysonski \& Durvasula 2008; Chu \& Lu 2007; Cronan \& Al-Rafee 2008; Cheung \& Prendergast 2006).

Perkembangan teknologi dan informasi memberikan pengaruh terhadap proses kemudahan, tidak hanya dalam akses, tapi juga kemanfaatan dan pengunaannya, meski di sisi lain ada ancaman risiko, baik human error atau technical error. Risiko tidak bisa terlepas dari perceived customer value (Chu \& Lu 2007). Keyakinan tentang aspek kemanfaatan juga terkait kebiasaan keperilakuan individu sehingga hal ini bisa disebut "habit" dan jika aspek kemanfaatan mengunduh mp3 dilakukan massal maka disebut social habit. Oleh karena itu, semakin besar kemanfaatan dari perilaku individu dalam mengunduh mp3 berpengaruh positif terhadap persepsi risiko (H1) sebagai konsekuensi dari intensitas online Hsu dan Shiue (2008) dan semakin besar kemanfaatan perilaku individu mengunduh mp3 berpengaruh positif terhadap kebiasaan keperilakuan secara massal (H2) sehingga jamak dilakukan (Cheung \& Prendergast 2006; Walsh et al., 2003). 
Pemahaman perceived usefulness dari penelitian ini terfokus kepada fungsi dan convenience benefits serta mengacu argumen Chu dan $\mathrm{Lu}$ (2007) yaitu: "perceived usefulness as the degree to which the consumer believes that listening to music online would fulfill the certain purpose". Oleh karena itu, hipotesis penelitian ini adalah sebagai berikut.

H1: Perceived usefulness berpengaruh positif terhadap perceived risk.

H2: Perceived usefulness berpengaruh positif terhadap social habit.

\section{Hubungan Perceived Playfulness dengan Perceived Risk}

Identifikasi daya tarik mp3 adalah kenikmatan memainkan musik di mana saja dan kapan saja karena diakses online. Hal ini menegaskan layanan musik di era online tidak hanya menyajikan kualitas audio, tetapi juga visualisasi yang menarik sehingga aspek mendasar musik online yaitu kepentingan untuk berselancar di dunia maya tanpa mengabaikan rekreasional sambil menikmati musik. Meskipun demikian tetap tidak bisa terlepas dari risiko, terutama virus atau spam. Selain itu, sifat rekreasional penikmat musik mp3 secara online yang dilakukan secara massal juga berpengaruh terhadap social habit. Oleh karena itu, semakin besar kenikmatan perilaku individu dalam mengunduh mp3 berpengaruh positif terhadap persepsi risiko (H3) sebagai konsekuensi intensitas online Hsu dan Shiue (2008) dan semakin besar kenikmatan perilaku individu dalam mengunduh mp3 berpengaruh positif terhadap kebiasaan keperilakuan secara massal (H4) sehingga hal ini jamak dilakukan (Cheung \& Prendergast 2006; Walsh et al., 2003). Perceived playfulness terfokus recreational benefit serta mengacu argumen Chu dan Lu (2007) yaitu: "perceived playfulness as the degree to which the consumer believes that enjoyment could be derived when listening to online music”. Oleh karena itu, hipotesis yang diajukan adalah sebagai berikut.

H3: Perceived playfulness berpengaruh positif terhadap perceived risk.

H4: Perceived playfulness berpengaruh positif terhadap social habit.

\section{Hubungan Perceived Price berpengaruh positif dengan Perceived Risk dan Social Habit}

Perilaku konsumen sangat rentan terhadap persepsian harga. Oleh karena itu, harga murah apalagi gratis mengunduh musik mp3 di internet menjadi alasan klasik kasus pembajakan musik di semua negara. Padahal, semakin murah apalagi gratis maka semakin memungkinkan konsumen terus berselancar mencari lagu-lagu lain di internet dan secara akumulatif menjadi social habit, meski di sisi lain ancaman risiko berselancar di dunia online tidak bisa dihindari. Hal ini menunjukan semakin besar persepsian harga gratis dalam mengunduh mp3 akan berpengaruh positif terhadap persepsi risiko (H5) sebagai konsekuensi dari intensitas online Hsu dan Shiue (2008) dan ini berpengaruh positif terhadap kebiasaan keperilakuan secara massal (H6) sehingga jamak dilakukan (Cheung dan Prendergast 2006; Walsh et al., 2003). Pemahaman perceived price terfokus kepada harga murah karena ini menjadi salah satu motivasi bagi consumer online 
Swatman, Krueger, dan Van Der Beek (2006) dan mengacu argumen dari Chu dan Lu (2007) yaitu: "perceived price as the degree to which the consumer believes that he/she must pay in money to obtain online music". Oleh karena itu, hipotesis yang diajukan adalah sebagai berikut.

H5: Perceived price berpengaruh positif terhadap perceived risk.

H6: Perceived price berpengaruh positif terhadap social habit.

\section{Hubungan antara Perceived Ease of Use dengan Perceived Risk dan Social Habit}

Perkembangan teknologi media dan internet memberikan berbagai kemudahan. Oleh karena itu, persepsian tentang kemudahan mengunduh mp3 lebih mengacu kepada minimalisasi usaha yang dilakukan seseorang untuk mendapatkan akses mp3. Padahal semakin mudah akses maka ancaman risiko juga semakin besar dan jika kemudahan akses ini dilakukan secara jamak maka hal ini juga berdampak terhadap social habit. Hal ini menegaskan semakin besar persepsian kemudahan mengunduh mp3 berpengaruh positif terhadap persepsi risiko (H7) sebagai konsekuensi dari intensitas online (Nill dan Shultz 2009; Hsu \& Shiue 2008) dan ini berpengaruh positif terhadap kebiasaan keperilakuan secara massal (H8) sehingga jamak dilakukan (Nill \& Shultz 2009; Cheung \& Prendergast 2006; Walsh et al., 2003). Pemahaman perceived ease of use terfokus kepada minimalisasi usaha yang dilakukan individu dalam mengunduh mp3 dan mengacu argumen Chu dan Lu (2007) yaitu: "perceived ease of use as the degree to which the consumer believes that listening to online music is effortless". Oleh karena itu, hipotesis yang diajukan adalah sebagai berikut.

H7: Perceived ease of use berpengaruh positif terhadap perceived risk.

H8: Perceived ease of use berpengaruh positif terhadap social habit.

\section{Hubungan antara Social Habit, Perceived Risk, Rationalization dan Piracy Intention}

Intensitas perilaku konsumen ketika mengunduh mp3 maka hal ini berpengaruh terhadap intensitas kunjungan terhadap situs tertentu sehingga memungkinkan terjadinya ancaman risiko kejahatan melalui internet semakin tinggi. Artinya, social habit sebagai dampak dari intensitas kunjungan terhadap musik yang sedang digemari pada akhirnya akan memicu ancaman risiko melalui internet, terutama melalui situs yang paling sering dikunjungi untuk men-download mp3. Interaksi positif antara social habit dengan risiko yang jamak dilakukan secara tidak langsung menunjukan bahwa perilaku ini dianggap sebagai sesuatu yang rasional karena media online melalui internet memungkinkan dan menyediakan mp3 secara gratis untuk diunduh. Selain itu, pemahaman tentang perilaku yang diyakini sebagai sesuatu yang rasional ini secara tidak langsung memperkuat niat individu untuk terus mengunduh musik format mp3 melalui internet sehingga fakta ini bisa menjadi ancaman serius bagi industri musik. Interaksi antara social habit, risiko, pemikiran rasional dan niat mengunduh musik mp3 di internet telah menjadi kajian yang sangat menarik (Phau et al., 2014; Vida et al., 2012; Sirkeci \& Magnúsdóttir 2011; 
Lysonski \& Durvasula 2008; Cheung \& Prendergast 2006; Walsh et al., 2003). Oleh karena itu, penjelasan tersebut menjadi pembentukan hipotesis sebagai berikut.

H9: Social habit berpengaruh positif terhadap perceived risk.

H10: Perceived risk berpengaruh positif terhadap razionalization.

H11: Social habit berpengaruh positif terhadap razionalization.

H12: Razionalization berpengaruh positif terhadap piracy intention.

Kompleksitas dalam memahami perilaku konsumen terkait mengunduh musik format mp3 maka model yang menjadi kajian dalam penelitian ini yaitu sebagai berikut:

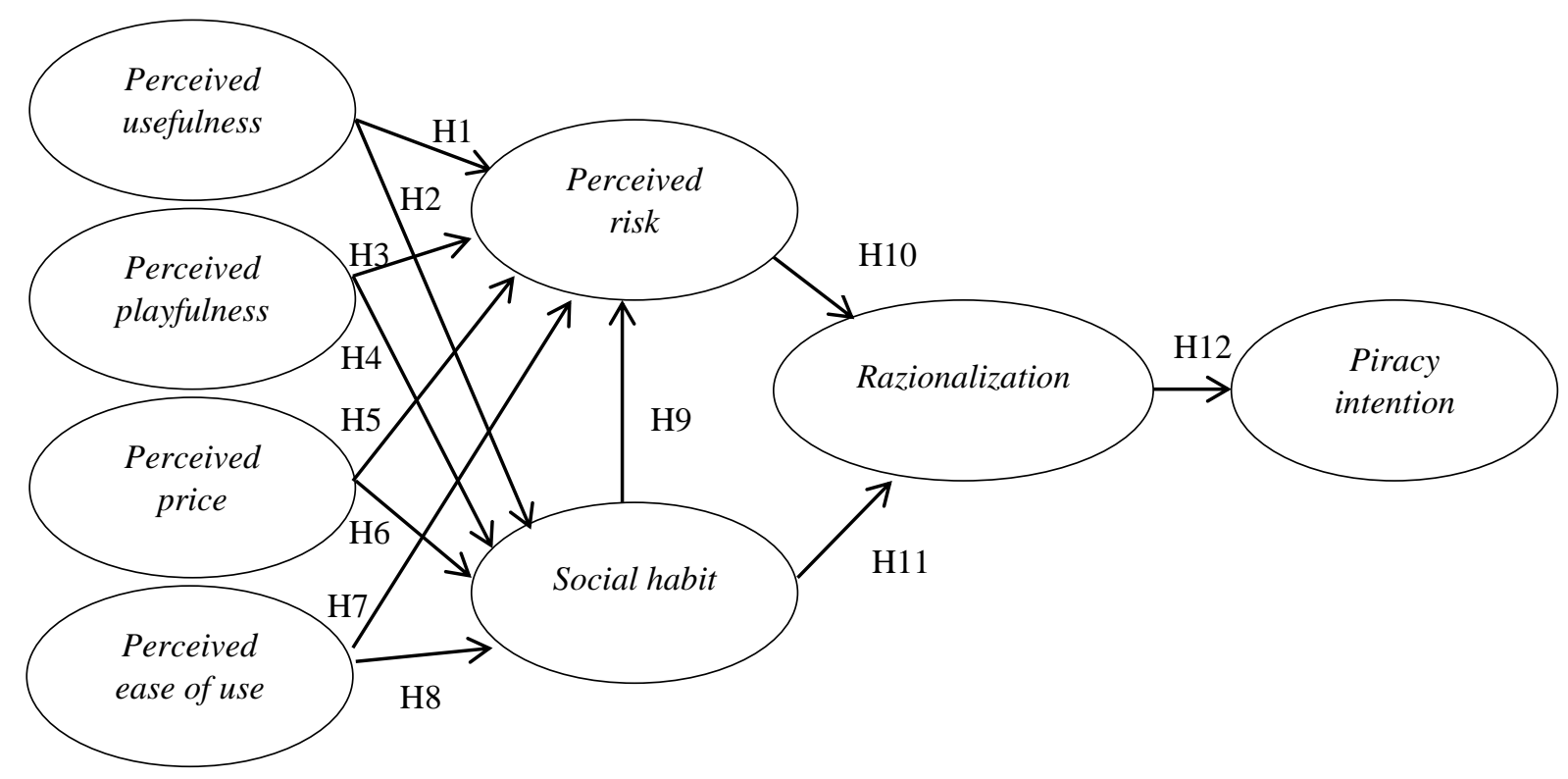

Gambar 1

Model Penelitian

\section{METODA PENELITIAN}

Fenomena pembajakan, terutama untuk kasus mp3 di industri musik kini justru semakin berkembang dan diyakini sebagai perilaku yang legal. Keyakinan ini tidak bisa terlepas dari adanya berbagai fasilitas di internet dan kemampuan piranti smartphone gadget yang memungkinkan mengunduh dan memutar musik format mp3 dimana saja dan kapan saja. Dualisme dari fenomena ini menimbulkan dampak negatif, meski di sisi lain juga memberikan manfaat bagi konsumen. Fakta ini berpengaruh terhadap perilaku konsumen yang enggan membeli produk versi original karena bisa mendapatkan produk sejenis dengan kualitas yang tidak kalah baiknya hanya dengan mengunduh melalui internet (Phau et al., 2014; Vida et al., 2012; Phau \& Liang 2012; Beekhuyzen et al., 2011; Sirkeci \& Magnúsdóttir, 2011; Williams et al., 2010; Lysonski \& Durvasula, 2008) 


\section{Pengumpulan Data dan Teknis Analisis}

Populasi penelitian ini adalah masyarakat yang berkebutuhan terhadap musik dan familier dengan era online. Oleh karena itu jumlah pasti dari populasi ini tidak dapat di ketahui, meskipun di sisi lain dapat diminimalisasi dengan keterwakilan mahasiswa sebagai identifikasi kelompok yang familier dengan era online dan juga berkebutuhan terhadap musik. Pembatasan ini secara tidak langsung mengindentifikasi keterlibatan peran mahasiswa sebagai sampel penelitian.

Pengumpulan data dalam penelitian ini menggunakan kuesioner ( 5 skala likert) dan responden yang terlibat yaitu mahasiswa mewakili karakteristik paham dunia online dan legalitas mengunduh musik mp3. Jumlah respoden 100 orang dari mahasiwa FEB UMS dan dilakukan secara random. Pemilihan mahasiswa sebagai responden mengacu berbagai riset yang menjadi acuan penelitian (Phau et al., 2014; Phau \& Liang 2012; Lysonski \& Durvasula 2008). Pemilihan mahasiswa sebagai responden mewakili karakteristik tentang perilaku konsumen yang paham tentang dunia online dan memiliki intensitas bagi pemenuhan kebutuhan terhadap musik.

Teknik analisis untuk uji hipotesis dilakukan dengan analisis struktural model yang menggunakan metoda maximum likelihood sesuai rekomendasi SEM adalah 100 orang (syarat minimal dari penggunaan metoda maximum likelihood yaitu 100 sampel). Pengujian struktural model penelitian ini merekomendasikan sejumlah prosedural untuk mendukung generalisasi hasil sesuai rekomendasi maximum likelihood dalam SEM.

Identifikasi pertanyaan dalam penelitian ini diadopsi dari sejumlah penelitian sebelumnya sehingga diharapkan mampu merefleksikan harapan untuk melihat model keperilakuan terhadap konsumsi produk bajakan, terutama untuk setting amatan di Solo terfokus kasus musik format mp3. Kuesioner penelitian ini terlihat pada tabel berikut:

Tabel 1

Pertanyaan Kuesioner Penelitian

\begin{tabular}{clcl}
\hline No & \multicolumn{1}{c}{ Variabel } & Item & \multicolumn{1}{c}{ Adopsi } \\
\hline 1 & Perceived usefulness & 4 & van der Heijden (2004); Davis (1989) \\
2 & Perceived playfulness & 4 & van der Heijden (2004) \\
3 & Perceived price & 4 & Sweeney et al. (1997); Tam (2004) \\
4 & Perceived ease of use & 4 & van der Heijden (2004); Davis (1989) \\
5 & Perceived risk & 5 & Hennig-Thurau et al. (2007) \\
6 & Social habit & 5 & Limayem et al. (2004) \\
7 & Razionalitasion & 4 & Skyes dan Matza (1957) (pada Vida et al., 2012) \\
8 & Piracy intention & 5 & Taylor dan Todd 1995; Limayem et al., 2004 \\
\hline
\end{tabular}

\section{ANALISIS DAN PEMBAHASAN}

\section{Karakteristik Responden}

Identifikasi karakteristik responden memberikan gambaran bahwa replikasi dari penelitian ini akan memberikan hasil yang tidak banyak perbedaan jika mengacu setting 
amatan sesuai dengan karakteristik responden yang sama. Oleh karena itu, identifikasi dari responden memberikan gambaran tentang profil obyek penelitian sehingga hasil ini mungkin berbeda jika setting amatan yang menjadi obyek penelitian juga berbeda.

Karakteristik responden menunjukkan mayoritas adalah berasal dari luar Solo $(85 \%)$ sedangkan yang berasal dari Solo (14\%) dan dari luar Jawa hanya 1\%. Mayoritas responden adalah pria (53\%), berusia lebih dari 21 tahun (67\%), tinggal di rumah kos $(55 \%)$, lama berinternet rata-rata lebih dari 10 jam per minggu (53\%), lokasi mengakses internet mayoritas di rumah (49\%), kebutuhan terhadap pencarian informasi merupakan faktor motivasi berinternet (52\%). Yang juga menarik dari identifikasi responden yaitu mayoritas pernah mengunduh musik mp3 $(74 \%)$ dan mayoritas merasa tidak bersalah dengan perilaku mengunduh musik mp3 (75\%) karena mayoritas teman dekatnya juga melakukan perilaku yang sama mengunduh musik mp3 (93\%). Faktor yang mendukung kegiatan berinternet adalah kecepatan akses (93\%).

Identifikasi aktivitas responden berinternet yang mayoritas mencari informasi (52\%) dan hiburan (40\%) menunjukan bahwa akses terhadap perilaku mengunduk musik mp3 adalah bagian dari kegiatan mencari informasi dan hiburan. Oleh karena itu, sangat beralasan jika identifkasi responden menunjukan mayoritas pernah mengunduh mp3 dan juga teman-temanya melakukan hal yang sama sehingga perasaan bersalah ketika harus mengunduh musik mp3 tidak dirasakan karena dianggap sebagai sesuatu yang wajar. Ini secara tidak langsung mengindikasikan bahwa social habit mengunduh mp3 tidak dapat dihindari dan kontinuitas dari perilaku ini dianggap sebagai rasionalitas sehingga sangat beralasan jika kemudian memicu niat untuk terus mengunduh.

\section{Uji Validitas dan Reliabilitas}

Pengujian validitas dan reliabilitas untuk memastikan semua item kuesioner mewakili karakteristik variabel amatan sehingga valid dan reliabel menjelaskan variabel tersebut. Uji validitas dilakukan analisis faktor trial and error untuk factor loading 0,5 (lampiran 1 dan 2). Uji reliabilitas dengan koefisien Cronbah's alpha >0,6 (Nunnally, 1978). Pengujian variabel PU hasil Cronbah's alpha (0,671), PP $(0,914), \mathrm{PC}(0,910), \mathrm{PE}$ $(0,787)$, PR (0,744), SH (0,750), RZ $(0,673)$, dan PI $(0,896)$.

\section{Asumsi Kecukupan Sampel}

AMOS 22 menyajikan 5 teknik estimasi yaitu salah satunya adalah Maximun Likelihood Estimation dengan rentang kebutuhan sampel 100-200 (Ghozali 2008). Oleh karena itu aspek kecukupan sampel dalam penelitian ini terpenuhi karena menggunakan Maximun Likelihood dengan jumlah sampel yaitu 100 orang. Asumsi kecukupan sampel adalah sangat penting untuk memenuhi batas minimal untuk proses analisis lebih lanjut.

\section{Asumsi Normalitas}

Uji asumsi normalitas adalah untuk mengetahui sebaran data apakah mendekati distribusi normal sebagai salah satu syarat analisis dengan menggunakan SEM. Asumsi normalitas univariate dilihat dari nilai critical ratio (c.r) pada skewness yaitu di bawah 
2,58 untuk $\alpha=1 \%$ dan normalitas multivariate dilihat dari assessment of normality yaitu nilai critical ratio kurtosis dibawah 2,58 untuk $\alpha=1 \%$ (Ghozali \& Fuad 2005). Hasil uji normalitas univariate menunjukan bahwa data dalam penelitian ini termasuk normal karena tidak ada nilai skewness $>2,58$, meskipun hasil uji multivariate menunjukan data penelitian ini termasuk tidak normal karena terdapat nilai critical ratio kurtosis diatas 2,58 yaitu PU1 dan SH3.

Persoalan normalitas data merupakan salah problem dari kasus data primer, sedangkan data dalam penelitian ini adalah persepsian individu sehingga sulit untuk bisa mendapatkan normalitas data. Oleh karena itu, bias interpretasi hasil akibat data tidak normal bisa diabaikan. Analisis terhadap data yang tidak normal dapat mengakibatkan bias hasil interpretasi karena $\chi^{2}$ cenderung meningkat sehingga probability level akan mengecil. Oleh karena penelitian ini memakai estimasi Maximum Likelihood maka tidak terlalu berpengaruh terhadap penyimpangan multivariate normality sehingga persoalan normalitas data bisa diabaikan (Ghozali \& Fuad 2005).

\section{Asumsi Outlier}

Asumsi outlier yaitu pengujian untuk mendeteksi karakteristik unik data dalam penelitian yang bisa muncul secara ekstrim (Hair et al., 1998). Pengujian asumsi outlier dilakukan dengan melihat Mahalanobis Distance untuk p <0,001. Mahalanobis distance dievaluasi dengan $\chi^{2}$ pada derajat bebas sebesar jumlah indikator penelitian dan apabila nilai Mahalanobis Distance lebih besar dari $\chi^{2}$ pada signifikansi $\mathrm{p}<0,001$ berarti terjadi outliers multivariate. Pengujian $\chi^{2}(27 ; 0.001)$ adalah 55.47602 sehingga ada 4 sampel melebihi batas yaitu sampel nomor $9(65,969)$, nomor $78(60,002)$, nomor $92(56,636)$ dan sampel nomor $35(56,608)$. Keempat sampel tersebut penting dalam membangun model penelitian ini sehingga persoalan outlier dapat diabaikan karena menghilangkan keempat sampel tidak berpengaruh terhadap perubahan model.

\section{Analisis Goodness of Fit Model}

Hasil analisis goodness fit of model secara umum menunjukan bahwa model dalam penelitian ini tidak fit. Hal ini mengindikasikan bahwa model yang dibangun dari penelitian ini tidak menjawab variabel yang mewakili model keperilakuan terhadap konsumsi produk bajakan. Oleh karena itu, perlu identifikasi teoritis dan konseptual terkait riset keperilakuan dalam kasus konsumsi produk bajakan.

Nilai $\chi^{2}$ menujukan bahwa semakin kecil $\chi^{2}$ berarti model semakin fit dengan datanya. Hasil analisis menunjukan bahwa nilai $\chi^{2}$ tidak fit dibanding cut off. Meskipun AMOS menyarankan modifikasi indeks namun secara umum perubahan yang dihasilkan dari modifikasi indeks tidak terlalu jauh berbeda sehingga dalam penelitian ini tidak melakukan tindakan modifikasi indeks sesuai saran AMOS. Selain itu, modifikasi indeks harus juga didukung justifikasi teoritis yang mendukungnya sehingga perubahan model sesuai saran modifikasi indeks dapat dibenarkan menurut kaidah ilmiah atau teoritis. Mengacu saran modifikasi indeks bahwa ada 5 saran yang dapat dilakukan karena nilai perubahannya adalah terbesar yaitu z4-z2 (modification indexs $=11.052)$, e11-e12 
(modification indexs $=12.388)$, e24-e9 $($ modification indexs $=10.963)$, e20-e26 (modification indexs $=11.082)$ dan e20-e21 (modification indexs $=10.047)$.

Uji CMIN/DF adalah nilai $\chi^{2}$ dibagi degree of freedom (df). Versi Wheaton et al. (1977) dalam Ghozali (2008), batasan yang menunjukan model fit $<5$ sehingga model disebut reasonable dan versi Byrne (1988) mengusulkan nilai ratio < 2 sebagai ukuran fit suatu model. Hasil analisis menunjukan nilai CMIN/DF dibawah cut off sehingga dapat disimpulkan bahwa model adalah fit.

Goodness of Fit Index (GFI) adalah ukuran non-statistik yang nilainya berkisar antara 0 (poor fit) sampai 1 (perfect fit) suatu model. Artinya, semakin tinggi nilai GFI semakin menunjukan model yang fit, begitu juga sebaliknya. Hasil analisis menunjukan nilai GFI 0,704 atau dibawah cut off sehingga disimpulkan model tidak fit (ibid 2008). Hasil ini menunjukan bahwa model penelitian ini tidak mampu menjawab identifikasi persoalan perilaku konsumsi produk bajakan sehingga perlu ekplorasi lebih lanjut terkait temuan kasus ini. Artinya, generalisasi model tidak bisa dilakukan karena mungkin hasil ini hanya berlaku pada setting amatan kasus penelitian ini. Oleh karena itu, penjelasan dari temuan ini menjadi acuan untuk penelitian lanjutan.

Root Mead Square Error of Approximation (RMSEA) merupakan suatu ukuran yang mencoba memperbaiki kecenderungan statistik $\chi^{2}$ menolak model dengan jumlah sampel yang besar (ibid 2008). Dari batas nilai yang disepakati menunjukan bahwa nilai RMSEA antara 0,05-0,08 merupakan ukuran model yang bisa diterima. Hasil uji empiris RMSEA cocok untuk menguji model konfirmatori dengan jumlah sampel besar. Artinya nilai RMSEA yaitu 0,078 atau dibawah cut off sehingga disimpulkan bahwa model fit.

Nilai RMR yang kecil menunjukan kovarian sampel mendekati nilai kovarian estimasi. Artinya, semakin kecil nilai RMR maka semakin menunjukan model fit, begitu juga sebaliknya. Oleh karena itu nilai RMR yang kecil dalam penelitian ini yaitu 0,078 menunjukan bahwa model sudah fit.

Adjusted goodness of fit atau AGFI merupakan pengembangan dari GFI yang disesuaikan dengan ratio degree of freedom (df) untuk proposed model dengan df untuk null model dan nilai rekomendasi untuk AGFI yaitu berkisar antara 0 (poor fit) sampai 1 (perfect fit) dan utamanya yaitu $\geq 0,9$ (ibid 2008). Oleh karena itu, semakin besar nilai AGFI semakin menunjukan bahwa model fit, begitu juga sebaliknya dan hasil penelitian menunjukan nilai AGFI 0,654 atau dibawah cut off sehingga disimpulkan bahwa model penelitian ini tidak fit. Hasil ini menegaskan bahwa model yang dibangun dalam riset ini tidak mampu menjelaskan keperilakuan dalam kasus konsumsi produk bajakan sehingga perlu eksplorasi teoritis dan konseptual lebih lanjut.

Tucker-Lewis Index atau TLI pada dasarnya ukuran ini menggabungkan ukuran parsimony kedalam indek komparasi antar proposed model dan null model. Nilai TLI berkisar antara 0-1 dan nilai TLI yang direkomendasikan $\geq 0,9$ (ibid 2008). Artinya, semakin besar TLI semakin menunjukan model adalah fit, begitu juga sebaliknya dan hasil menunjukan TLI 0,810 atau dibawah cut off yang ditetapkan sehingga disimpulkan model tidak fit. Penjelasan dari temuan ini juga menunjukan bahwa model tidak mampu mengidentifikasi keperilakuan konsumsi produk bajakan sesuai setting amatan kasus ini. 
Comparative Fit Index (CFI) merupakan bagian indeks keesuaian incremental. Besaran indeks yaitu interval 0-1 dan nilai yang mendekati 1 mengindikasikan model memiliki tingkat kesesuaian yang baik. Indeks ini dianjurkan dipakai karena indeks ini tidak sensitif terhadap besarnya sampel dan kurang dipengaruhi oleh kerumitan model. Nilai yang direkomendasikan $\mathrm{CFI} \geq 0,90$ dan hasil analisis menunjukan bahwa nilai CFI 0,827 atau dibawah cut off sehingga disimpulkan bahwa model tidak fit.

Identifikasi temuan sejumlah kriteria yang tidak sesuai dengan cut off sehingga menunjukan hasil tidak fit secara tidak langsung mengindikasikan bahwa model yang dibangun dalam penelitian ini tidak mampu menjawab keperilakuan dalam konsumsi produk bajakan. Hal ini bisa dipengaruhi oleh beberapa faktor misalnya kajian tentang konsep teoretis yang kurang, pemilihan sampel yang tidak tepat dan juga faktor lainnya.

Tabel 2

Hasil Analisis Goodness of Fit Model

\begin{tabular}{lrrl}
\hline \multicolumn{1}{c}{ Kriteria } & \multicolumn{1}{c}{ Hasil } & Cut Off & \multicolumn{1}{c}{ Ket } \\
\hline$\chi^{2}$ chi square & 723.830 & Kecil & \\
$\chi^{2}$ sig probly & 0,000 & $\geq 0,05$ & Relatif Fit \\
CMIN/DF & 1,601 & $\leq 2,00$ & Fit \\
GFI & 0,704 & $\geq 0,90$ & Relatif Fit \\
RMSEA & 0,078 & $\leq 0,80$ & Fit \\
RMR & 0,078 & Kecil & Fit \\
AGFI & 0,654 & $\geq 0,90$ & Relatif Fit \\
TLI & 0,810 & $\geq 0,90$ & Relatif Fit \\
CFI & 0,827 & $\geq 0,90$ & Relatif Fit \\
\hline
\end{tabular}

Sumber: hasil olah data

\section{Uji Hipotesis}

Tabel 3 menunjukkan bahwa $\mathrm{H} 1$ yang menyatakan perceived usefulness (PU) berpengaruh positif terhadap perceived risk (PR) tidak didukung dan hal ini berlawanan dengan argumen Hsu dan Shiue (2008). Hasil ini secara tidak langsung membenarkan fenomena bahwa perkembangan teknologi dan internet bersinergi dengan berbagai penangkal dari perkembangannya. Oleh karena itu, era perkembangan teknologi dan internet juga menyajikan berbagai anti virus dan berbagai model pengamanan, baik dalam bentuk hardware ataupun software sehingga tetap dapat memungkinkan orang mengakses teknologi dan internet secara aman dan nyaman tanpa perlu risau dengan ragam ancaman, baik dalam bentuk human error atau technical error. Hasil ini secara tidak langsung menolak argumen semakin mudah adopsi teknologi yang ada maka semakin memicu kerawanan terhadap risiko. Meski demikian, hasil ini juga mendukung argumen bahwa persepsian risiko itu sendiri tetap tidak dapat terlepas dari perceived customer value karena setiap individu pada intinya tetap memiliki persepsian terhadap risiko dan persepsian tentang kemudahan teknologi terbaru (Chu \& Lu 2007).

Hasil pengujian menunjukan bahwa $\mathrm{H} 2$ yang menyatakan perceived usefulness (PU) berpengaruh positif terhadap social habit (SH) tidak didukung dan ini berlawanan dengan riset sebelumnya (Cheung \& Prendergast 2006; Walsh et al., 2003). Secara 
konseptual diyakini aspek kemanfaatan yang dapat dirasakan dari suatu teknologi akan berpengaruh terhadap kebiasaan yang jamak dilakukan secara massal. Meski demikian perkembangan teknologi internet yang masih terkendala terhadap kecepatan akses secara tidak langsung memberikan pengaruh terhadap kenyamanan dan kenikmatan terhadap kebutuhan untuk berinternet. Oleh karena itu, identifikasi karakteristik responden yang menyatakan nilai terpenting dari akses internet adalah kecepatan akses menjadi argumen yang mendasari $\mathrm{H} 2$ tidak didukung. Hasil ini juga diperkuat alasan kebutuhan internet yaitu mencari informasi dan hiburan sedangkan mayoritas akses dilakukan di rumah kos. Hasil ini menjadi argumen bahwa kecepatan akses menjadi salah satu faktor yang mendukung social habit terkait persepsian kemanfaatan, termasuk dalam mengunduh musik mp3. Selain itu, hasil ini juga sejalan dengan argumen Chu dan Lu (2007) bahwa perkembangan internet dalam kasus mengunduh musik mp3 terkait dengan convenience benefits. Hasil ini menguatkan argumen bahwa ancaman akses yang lemot dari sistem prabayar menjadi faktor yang tidak mendukung hipotesis ini.

Pengujian $\mathrm{H} 3$ yang menyatakan bahwa perceived playfulness (PP) berpengaruh positif terhadap perceived risk (PR) menunjukan hasil yang tidak didukung dan hasil ini berlawanan dengan argumen Hsu dan Shiue (2008). Realitas ini pada dasarnya tidak bisa terlepas dari temuan $\mathrm{H} 1$ yang berkaitan dengan aspek risiko di dunia online-internet. Oleh karena itu, aspek rekreasional yang menjadi bagian penting di era online bisa didukung ketersediaan software dan hardware untuk menjamin keamanan sehingga semua ancaman risiko dapat direduksi, baik human error ataupun technical error. Temuan ini secara tidak langsung menguatkan argumen bahwa tuntutan terhadap aspek rekreasional, termasuk dalam kasus mengunduh musik mp3 merupakan bagian dari kebutuhan terhadap aspek rekreasional dan hal ini sejalan dengan alasan dari responden yang menyatakan bahwa faktor utama kebutuhan berinternet adalah mencari informasi dan hiburan. Artinya temuan ini menguatkan argumen Chu dan Lu (2007) dari aspek pentingnya enjoyment dalam memanfaatkan teknologi internet.

Hasil analisis menunjukan bahwa $\mathrm{H} 4$ yang menyatakan perceived playfulness (PP) berpengaruh positif terhadap social habit (SH) tidak didukung dan berlawanan dengan temuan riset sebelumnya (Cheung \& Prendergast 2006; Walsh et al., 2003). Temuan ini secara tidak langsung menunjukan kontradiksi dengan pemahaman dari hasil H3 karena di satu sisi aspek rekreasional tidak berpengaruh terhadap risiko, namun di sisi lain hal ini justru tidak didukung terhadap social habit. Asumsi yang mendasari pada dasarnya tidak bisa terlepas dari argumen $\mathrm{H} 2$ sehingga pertimbangan kecepatan akses menjadi dasar yang mendukung aspek rekreasional ketika individu mengakses internet untuk bisa memenuhi kebutuhan, termasuk kebutuhan hiburan menikmati musik mp3. Artinya, hal ini bisa menjadi nilai penting bahwa aspek rekreasional yang membentuk social habit harus bisa didukung dengan kecepatan akses sehingga argumen Chu dan Lu (2007) tentang urgensi enjoyment dalam dunia online-internet terjawab.

Persepsian tentang harga yang menjadi dasar dalam keperilakuan konsumen di era internet menjadi salah satu isu yang menarik, termasuk dalam kasus mengunduh mp3 terutama dikaitkan dengan akses yang semakin mudah dan murah. Oleh karena itu, fakta 
ini tidak bisa terlepas dari aspek risiko, namun penjelasan $\mathrm{H} 1$ dan $\mathrm{H} 3$ menguatkan asumsi bahwa H5 yang menyatakan bahwa perceived price (PC) berpengaruh positif terhadap perceived risk (PR) tidak didukung dalam penelitian ini. Artinya temuan ini mendukung argumen bahwa mengunduh musik mp3 secara gratis tidak bisa terlepas dari persepsian tentang harga (Swatman, Krueger, \& Van Der Beek 2006), meski di sisi lain hasil ini juga sependapat dengan Chu dan $\mathrm{Lu}$ (2007) terutama terkait dengan persepian mengunduh musik secara online. Selain itu, hasil dari uji hipotesis H6 yang menyatakan perceived price (PC) berpengaruh positif terhadap social habit (SH) juga tidak didukung. Penjelasan dari kasus ini sejalan dengan temuan $\mathrm{H} 2$ dan $\mathrm{H} 4$ diatas. Artinya, kemudahan dan ketersediaan secara mudah dan murah dari layanan internet harus bersinergi dengan tuntutan kecepatan akses sehingga terbentuknya social habit dapat didukung.

Perkembangan teknologi internet menjanjikan berbagai kemudahan, termasuk salah satunya adalah menikmati musik mp3 secara online. Keberagaman kemudahan ini secara tidak langsung memicu pihak-pihak lain untuk mencari keuntungan sepihak yang justru bisa merugikan pihak lain dan karenanya sangat beralasan jika kasus-kasus yang berkaitan dengan pencurian identitas diri melalui situs jejaring marak terjadi. Selain itu, kasus phising (tampilan website yang mirip dengan aslinya) juga semakin berkembang dan hal ini akan menjebak individu yang tidak jeli melihat situs-situs online, termasuk juga situs yang menyajikan fasilitas unduh musik mp3 secara gratis. Fakta ini kemudian menjadi ancaman terhadap risiko dan karenanya $\mathrm{H} 7$ yang menyatakan perceived ease of use (PE) berpengaruh positif terhadap perceived risk (PR) didukung. Artinya meskipun ada berbagai software antivirus, namun akses ancaman virus tetap ada dan juga ancaman dari kejahatan lainnya dari pihak-pihak yang mencari keuntungan dari berbagai fasilitas kemudahan yang disajikan oleh internet, termasuk juga menjebak individu yang gemar mengunduh musik mp3 dari internet. Temuan ini sekaligus menguatkan argumen yang menjadi dasar pembentukan $\mathrm{H} 8$ yang menyatakan bahwa perceived ease of use (PE) berpengaruh positif terhadap Social Habit $(\mathrm{SH})$ karena kemudahan yang dijanjikan akan memengaruhi perilaku individu untuk terus berselancar di dunia maya dan kemudian ini berlanjut melalui word-of-mouth, terutama untuk situs-situs yang menjanjikan jenis unduhan gratis berbagai bentuk, baik musik, film atau sumber informasi-hiburan yang lainnya. Oleh karena itu, temuan ini mendukung argumen Chu dan Lu (2007).

Penelitian ini mengajukan 4 variabel yang menjadi dasar keperilakuan dalam mengunduh musik mp3 yaitu: perceived usefulness (PU), perceived playfulness (PP), perceived price (PC) dan perceived ease of use ( $\mathrm{PE}$ ) yang berpengaruh positif terhadap perceived risk (PR). Dari keempat variabel tersebut ternyata hanya satu variabel yaitu perceived ease of use (PE) yang mendukung pengaruh positif terhadap perceived risk (PR) sedangkan tiga diantaranya tidak mendukung dari konsep dan teoritis yang menjadi argumen pembentukan hipotesis dari ketiga variabel tersebut. Oleh karena itu, $\mathrm{H}_{9}$ yang menyatakan social habit $(\mathrm{SH})$ berpengaruh positif terhadap perceived risk (PR) tidak didukung dan temuan ini secara tidak langsung menguatkan temuan ketiga variabel yang sebelumnya, meski ada satu variabel yaitu perceived ease of use (PE) yang mendukung pengaruh positif terhadap perceived risk (PR). 
Hasil pengujian hipotesis juga menunjukkan hasil yang menarik yaitu persepsian tentang pemahaman rasional terkait perilaku mengunduh musik mp3 karena persepsian tentang risiko dan social habit tidak didukung dari hasil penelitian ini. Oleh karena itu, H10 yang menyatakan perceived risk (PR) berpengaruh positif terhadap razionalization (RZ) dan $\mathrm{H}_{11}$ yang menyatakan bahwa Social Habit $(\mathrm{SH})$ berpengaruh positif terhadap razionalization (RZ) tidak didukung. Hasil ini menguatkan temuan sebelumnya bahwa pengaruh variabel perceived risk dalam kasus mengunduh musik mp3 tidak didukung, kecuali untuk pengaruhnya terhadap perceived ease of use. Hasil ini juga menguatkan hasil temuan sebelumnya terkait variabel social habit bahwa tidak mendukung terhadap keperilakuan mengunduh musik mp3, kecuali untuk keterkaitan perceived ease of use.

Temuan lain yang juga menarik dikaji adalah adanya hubungan antara perilaku rasional yang dilakukan secara jamak terhadap niat mengunduh musik mp3 di internet. Oleh karena itu H12 yang menyatakan razionalization (RZ) berpengaruh positif terhadap piracy intention (PI) didukung. Hasil ini menarik dikaji karena hubungan antara variabel yang membentuk razionalization yaitu perceived risk dan social habit ternyata justru tidak mendukung dalam pengembangan hipotesis dalam penelitian ini. Temuan ini secara tidak langsung menjadi bahan diskusi yang menarik, terutama apabila dikaitkan argumen dari hasil sejumlah riset (Phau et al., 2014; Vida et al., 2012; Sirkeci \& Magnúsdóttir 2011; Lysonski \& Durvasula 2008; Cheung \& Prendergast 2006; Walsh et al., 2003).

Tabel 3

Hasil Analisis Hipotesis

\begin{tabular}{|c|c|c|c|c|c|c|c|c|}
\hline \multicolumn{3}{|c|}{ Hipotesis } & \multirow{2}{*}{$\begin{array}{c}\mathbf{H} \\
\mathrm{H}_{1}\end{array}$} & \multirow{2}{*}{$\begin{array}{r}\text { Estimate } \\
-0,190\end{array}$} & \multirow{2}{*}{$\begin{array}{l}\text { S.E. } \\
0,157\end{array}$} & \multirow{2}{*}{$\begin{array}{l}\text { C.R. } \\
-1,214\end{array}$} & \multirow{2}{*}{\begin{tabular}{c|}
$\mathbf{P}$ \\
0,225
\end{tabular}} & \multirow{2}{*}{$\frac{\text { Keterangan }}{\text { Tidak Signifikan }}$} \\
\hline PR & $\begin{array}{l}<-- \\
\end{array}$ & $\mathrm{PU}$ & & & & & & \\
\hline SH & <--- & PU & $\mathrm{H}_{2}$ & 0,161 & 0,181 & 0,890 & 0,373 & Tidak Signifikan \\
\hline PR & $<---$ & PP & $\mathrm{H}_{3}$ & 0,096 & 0,078 & 1,226 & 0,220 & Tidak Signifikan \\
\hline SH & <--- & PP & $\mathrm{H}_{4}$ & $-0,005$ & 0,081 & $-0,061$ & 0,951 & Tidak Signifikan \\
\hline PR & $<---$ & $\mathrm{PC}$ & $\mathrm{H}_{5}$ & 0,108 & 0,071 & 1,519 & 0,129 & Tidak Signifikan \\
\hline SH & $<---$ & $\mathrm{PC}$ & $\mathrm{H}_{6}$ & 0,015 & 0,072 & 0,202 & 0,840 & Tidak Signifikan \\
\hline PR & $<---$ & PE & $\mathrm{H}_{7}$ & $-0,361$ & 0,207 & $-1,748$ & 0,080 & Signifikan* \\
\hline SH & $<---$ & PE & $\mathrm{H}_{8}$ & 0,478 & 0,218 & 2,194 & 0,028 & Signifikan** \\
\hline PR & $<---$ & SH & $\mathrm{H}_{9}$ & $-0,005$ & 0,144 & $-0,037$ & 0,971 & Tidak Signifikan \\
\hline RZ & $<---$ & PR & $\mathrm{H}_{10}$ & 0,327 & 0,206 & 1,588 & 0,112 & Tidak Signifikan \\
\hline RZ & $<---$ & SH & $\mathrm{H}_{11}$ & 0,095 & 0,184 & 0,515 & 0,607 & Tidak Signifikan \\
\hline PI & $<--$ & RZ & $\mathrm{H}_{12}$ & $-0,185$ & 0,089 & $-2,076$ & 0,038 & Signifikan* \\
\hline
\end{tabular}

Penjelasan hasil uji hipotesis memberikan gambaran yang detail tentang model keperilakuan yang dibangun sesuai setting amatan dalam penelitian ini sebagai berikut: 


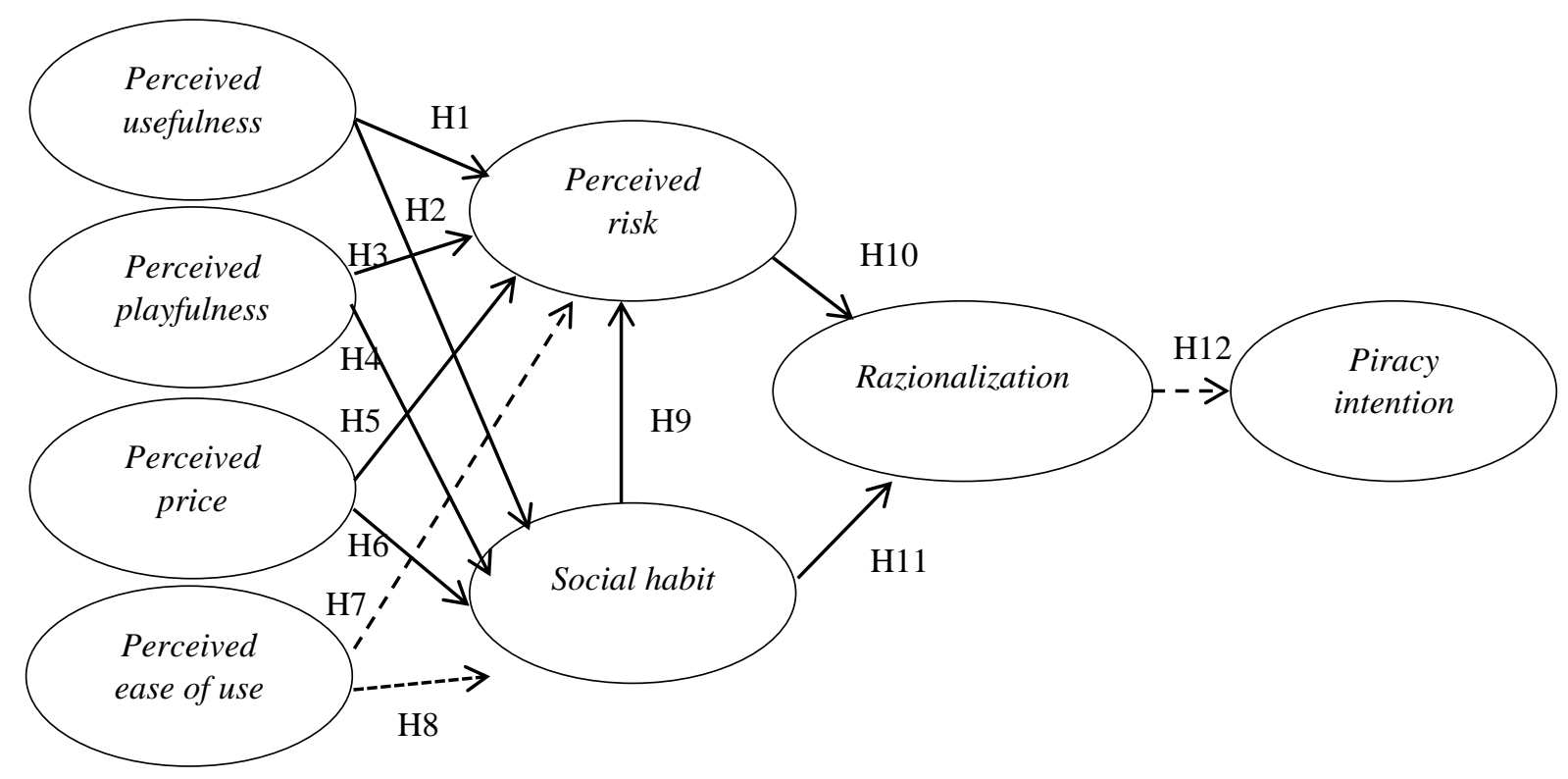

Gambar 2

Hasil Uji Hipotesis

\section{Pembahasan}

Riset keperilakuan adalah salah satu isu menarik dan kasus mengunduh musik mp3 di era internet merupakan kajian yang relevan terutama dikaitkan realitas semakin mudahnya akses yang didukung tarif murah sehingga memungkinkan mendapat layanan internet secara mudah-murah. Oleh karena itu, faktor yang memengaruhi keperilakuan mengunduh musik mp3 di internet cenderung semakin berkembang dan beragam (Phau et al., 2014; Anaza \& Zhao 2013; Phau \& Liang 2012; Sirkeci \& Magnúsdóttir 2011). Artinya, setting amatan menjadi faktor penting memahami keperilakuan dalam mengunduh mp3 (Sirkeci \& Magnúsdóttir 2011; Lysonski \& Durvasula 2008; Chu \& Lu 2007; Cheung \& Prendergast 2006; Swatman et al., 2006).

Hasil penelitian yang menegaskan pengaruh aspek kemudahan mengakses yang sekaligus mengunduh musik mp3 memberi gambaran yang jelas bahwa hal ini menjadi persoalan terutama dikaitkan dengan hak cipta dan pajak. Bahkan, realitas ini semakin didukung dengan temuan pengaruh rasionalisasi tentang pemikiran bahwa mengunduh musik mp3 di internet adalah sesuatu yang wajar karena dilakukan secara jamak, tidak hanya di negara industri-maju, tapi juga di negara miskin-berkembang. Oleh karena itu, temuan ini menjadi warning tentang pentingnya membangun budaya sehat mengunduh karya cipta (Vida et al., 2012; Tewell 2010; Williams et al., 2010). Selain itu, temuan tentang tidak didukungnya sejumlah variabel dalam penelitian ini tidak secara langsung bisa mengabaikan keperilakuan dalam mengunduh musik mp3. Artinya, kasus ini terjadi dalam setting amatan yang berbeda sehingga ketika direplikasi pada setting amatan lain mungkin hasilnya akan berbeda. Oleh karena itu, semua temuan tentang keperilakuan di era internet-online menjadi acuan untuk memetakan berbagai persoalan terkait perilaku 
individu mengunduh musik mp3, tidak hanya saat ini, tapi juga di masa mendatang. Hal ini juga releven dengan kepentingan pembuatan regulasi.

Esensi dari hasil penelitian ini secara tidak langsung memberikan gambaran riil tentang perkembangan industri musik mendatang karena jika dicermati ternyata perilaku konsumen terhadap industri musik telah berubah (Wilcox 2003). Teoritis menyebutkan bahwa semua perubahan perilaku konsumen menuntut adanya penyesuaian dari industri yaitu apakah tetap berproduksi untuk memenuhi perubahan selera kebutuhan atau justru mengabaikan perubahan itu sendiri, sementara tantangan dengan kehadiran inovasi terus berkembang, belum lagi masuknya pesaing baru di industri musik. Artinya perubahan ini menjadi tantangan bagi industri musik karena perkembangan teknologi digitalisasi telah merubah semuanya (Stevans \& Sessions 2005; Rao 2003; Mathews 2001).

Urgensi terhadap tuntutan perubahan tersebut maka secara tidak langsung fakta industri musik dihadapkan kepada dua pilihan yaitu tentang hak cipta dan gadget. Tidak bisa disangkal bahwa hak cipta terkait dengan kekayaan intelektual sebagai penghargaan karya cipta sehingga industri musik juga berkepentingan dengan hak cipta (Limayem, Khalifa, \& Chin 2004; Lysonski \& Durvasula 2008; Cronan \& Al-Rafee 2008; Cheung \& Prendergast 2006; Doherty 2006; Dong et al., 2002). Selain itu perkembangan piranti gadget secara tidak langsung juga berpengaruh terhadap perilaku mengunduh musik mp3 di era online. Fenomena ini juga terkait dengan mobilitas individu yang saat ini semakin tinggi sehingga membutuhkan gadget yang mampu mengkoneksikan semua kebutuhan, mulai dari transaksi perbankan sampai informasi-hiburan. Oleh karena itu, era perkembangan teknologi termasuk gadget menjadi faktor penting dibalik keperilakuan mengunduh mp3 dengan berbagai konsekuensinya (Lutz 2004; Fullerton \& Schmidt 2005; Lewis, Graham, \& Hardaker 2005; Graham et al., 2004; Kwong et al., 2003).

Fenomena mengunduh musik mp3 yang diyakini sebagai perilaku anti-sosial ini tidak bisa dicegah, meski di sisi lain ada kerugian yang tidak bisa diremehkan. Relevan dengan fenomena ini maka edukasi menjadi faktor penting untuk dilakukan dan semua pihak yang berkompeten harus dilibatkan, tidak hanya pemerintah dan industri musik. Edukasi harus dilakukan secara kontinu dan berkelanjutan. Selain itu, fatwa keagamaan mungkin juga perlu dilakukan untuk mereduksi semakin jamaknya keperilakuan tentang mengunduh musik mp3. Proses edukasi yang berhasil secara tidak langsung akan dapat membentuk kesadaran kolektif sehingga mengunduh mp3 tidak lagi dianggap rasional, tapi justru anti-sosial sehingga jumlahnya dapat direduksi dan intensitas membeli versi orisinil semakin meningkat sehingga perolehan hak cipta dan pajak meningkat. Langkah ini juga bisa didukung dengan melakukan pemblokiran terhadap situs-website yang menyajikan unduhan musik mp3 secara gratis. 


\section{SIMPULAN, KETERBATASAN DAN SARAN}

Model yang dibangun dari penelitian ini tidak fit dalam menjelaskan persoalan keperilakuan konsumsi produk bajakan sehingga generalisasi hasil tidak bisa dilakukan karena setting amatan dari penelitian ini tidak terwakili dalam model yang dibangun. Oleh karena itu, eksplorasi terhadap penelitian lebih lanjut perlu dilakukan, terutama mengacu konsep-teoritis yang lebih mendalam, selain mempertimbangkan sampelnya.

Hasil menunjukkan variabel perceived ease of use adalah faktor penting dari kasus keperilakuan mengunduh musik mp3 dalam setting amatan penelitian ini. Selain itu, pemahaman rasionalisasi mengunduh musik mp3 yang jamak dilakukan menjadi ancaman terkait niat mengunduh musik mp3. Oleh karena itu hasil penelitian ini menjadi warning terkait perilaku anti-sosial yang tanpa didasari semakin berkembang. Urgensi temuan penelitian terkait dengan pemerintah karena nilai perpajakan dan industri musik sebagai acuan pengembangan bisnis musik. Penyedia layanan internet juga terkait hasil penelitian ini karena faktor kecepatan layanan akses menjadi pertimbangan utama, selain faktor kepentingan untuk dapat memenuhi kebutuhan terhadap pencarian informasi dan hiburan. Artinya, pihak-pihak yang terlibat mempunyai kewenangan dan kepentingan sehingga bisa memberikan kontribusi terhadap semua pihak untuk mereduksi ancaman terjadinya keperilakuan mengunduh musik mp3 ke depan.

\section{Keterbatasan}

Model yang dibangun dalam penelitian ini tidak fit dalam kasus keperilakuan konsumsi produk bajakan sehingga generalisasi hasilnya tidak bisa dilakukan. Meskipun demikian, temuan penelitian ini memberikan gambaran pentingnya keterlibatan sejumlah pihak dalam mensikapi realitas keperilakuan mengunduh musik mp3. Meski demikian, penelitian ini memiliki keterbatasan yaitu tidak menggunakan pendekatan longitudinal. Hal ini penting terutama jika dikaitkan komitmen membangun nilai kesadaran kolektif melalui edukasi. Artinya, dengan pendekatan longitudinal dapat dipetakan permasalahan mendasar dari keperilakuan mengunduh musik mp3. Selain itu, keterbatasan lain adalah keterlibatan mahasiswa sebagai responden, meski keterlibatan ini jamak dilakukan dan sekaligus mewakili karakteristik konsumen yang familier di era internet-online, namun pemahaman terhadap norma sosial masih relatif rendah.

\section{Saran}

Temuan dan keterbatasan dari penelitian ini memberikan peluang untuk proses penelitian lanjutan. Penelitian lanjutan perlu melakukan pendekatan riset longitudinal sehingga bisa dipetakan faktor penting keperilakuan mengunduh musik mp3. Penelitian longitudinal diharapkan bisa dilakukan secara komprehensif dengan rentang waktu yang relatif cukup panjang sehingga temuan yang dihasilkan dapat menjawab persoalan riil dari kasus keperilakuan mengunduh mp3. Selain itu, penelitian mendatang juga perlu memperluas cakupan responden tidak hanya melibatkan mahasiswa, tapi juga usia remaja (usia SMP-SMA) karena mereka adalah segmen pasar potensial dari industri musik sehingga juga rentan terhadap keperilakuan untuk berniat mengunduh musik mp3. 


\section{DAFTAR PUSTAKA}

Amberg, Michael, dan Manuela Schröder. 2007. "E-business models and consumer expectations for digital audio distribution." Journal of Enterprise Information Management 20 (3): 291-303. https://doi.org/10.1108/17410390710740745.

Anaza, Nwamaka A., dan Jing Zhao. 2013. "Encounter-based antecedents of e-customer citizenship behaviors." Journal of Services Marketing 27 (2): 130-40. https://doi.org/10.1108/08876041311309252.

Beekhuyzen, Jenine, Liisa Von Hellens, dan Sue Nielsen. 2011. "Underground online music communities: Exploring rules for membership." Online Information Review 35 (5): 699-715. https://doi.org/10.1108/14684521111176453.

Brodie, Roderick J., Heidi Winklhofer, Nicole E. Coviello, dan Wesley J. Johnston. 2007. "Is e-marketing coming of age? An examination of the penetration of e-marketing and firm performance." Journal of Interactive Marketing 21 (1): 2-21. https://doi.org/10.1002/dir.20071.

Cheung, Wah Leung, dan Gerard Prendergast. 2006. "Buyers' perceptions of pirated products in China." Marketing Intelligence and Planning 24 (5): 446-62. https://doi.org/10.1108/02634500610682854.

Chu, Ching W., dan Hsi Peng Lu. 2007. "Factors influencing online music purchase intention in Taiwan: An empirical study based on the value-intention framework." Internet Research 17 (2): 139-55. https://doi.org/10.1108/10662240710737004.

Colla, Enrico, dan Paul Lapoule. 2012. "E- commerce: Exploring the critical success factors." International Journal of Retail \& Distribution Management 40 (11): 842-64. https://doi.org/10.1108/09590551211267601.

Cronan, Timothy Paul, dan Sulaiman Al-Rafee. 2008. "Factors that influence the intention to pirate software and media." Journal of Business Ethics 78 (4): $527-$ 45. https://doi.org/10.1007/s10551-007-9366-8.

Doherty, Will. 2006. “Copyright theft.” Industrial and Commercial Training 38 (7): 37178. https://doi.org/10.1108/00197850610704570.

Dong, Ying, Mingshu Li, Meizhang Chen, dan Shengli Zheng. 2002. "Research on intellectual property right problems of peer-to-peer networks." Electronic Library 20 (2): 143-50. https://doi.org/10.1108/02640470210424482.

Fullerton, Barbara, dan Aaron Schmidt. 2005. "Gadget review: A look at devices for work, home and play." Library Hi Tech News 22 (4): 13-17. https://doi.org/10.1108/07419050510604639.

Ghozali, Imam. 2008. Model persamaan struktural: Konsep dan aplikasi dengan program AMOS 16.0. 3ed. Semarang: Badan Penerbit Universitas Diponegoro.

Ghozali, Imam, dan Fuad. 2005. Struktural equation modelling: Pengantar. Semarang: 
Badan Penerbit Universitas Diponegoro.

Graham, Gary, Bernard Burnes, Gerard J. Lewis, dan Janet Langer. 2004. "The transformation of the music industry supply chain: A major label perspective." International Journal of Operations and Production Management 24 (11): 10871103. https://doi.org/10.1108/01443570410563241.

Hair, J.F., R.E. Anderson, R.L. Tatham, dan W.C. Black. 1998. Multivariate data analysis with readings (5nd ed.). Prentice-Hall, Upper Saddle River. New Jersey.

Hsu, Jane L., dan Charlene W. Shiue. 2008. “Consumers' willingness to pay for nonpirated software." Journal of Business Ethics 81 (4): 715-32. https://doi.org/10.1007/s10551-007-9543-9.

Kwong, Kenneth K., Oliver H.M. Yau, Jenny S.Y. Lee, Leo Y.M. Sin, dan Alan C.B. Tse. 2003. "The Effects of Attitudinal and Demographic Factors on Intention to Buy Pirated CDs: The Case of Chinese Consumers." Journal of Business Ethics 47 (3): 223-35. https://doi.org/10.1023/A:1026269003472.

Lewis, Gerard J., Gary Graham, dan Glenn Hardaker. 2005. "Evaluating the impact of the internet on barriers to entry in the music industry." Supply Chain Management: An International Journal $10 \quad$ (5): 349-56. https://doi.org/10.1108/13598540510624179.

Limayem, Moez, Mohamed Khalifa, dan Wynne W. Chin. 2004. "Factors motivating software piracy: A longitudinal study." IEEE Transactions on Engineering Management 51 (4): 414-25. https://doi.org/10.1109/TEM.2004.835087.

Lutz, Marilyn. 2004. "The Maine music box: A pilot project to create a digital music library." Library Hi Tech $22 \quad$ (3): $283-94$. https://doi.org/10.1108/07378830410560080.

Lysonski, Steven, dan Srinivas Durvasula. 2008. "Digital piracy of MP3s: Consumer and ethical predispositions." Journal of Consumer Marketing 25 (3): 167-78. https://doi.org/10.1108/07363760810870662.

Mathews, A. W. 2001. "Royalty fight threatens record industry's plans to deliver songs online." The Wall Street Journal 1.

Nill, Alexander, dan Clifford J. Shultz. 2009. "Global software piracy: Trends and strategic considerations." Business Horizons $52 \quad$ (3): 289-98. https://doi.org/10.1016/j.bushor.2009.01.007.

Phau, Ian, dan Johan Liang. 2012. "Downloading digital video games: Predictors, moderators and consequences." Marketing Intelligence and Planning 30 (7): 74056. https://doi.org/10.1108/02634501211273832.

Phau, Ian, Aaron Lim, Johan Liang, dan Michael Lwin. 2014. "Engaging in digital piracy of movies: A theory of planned behaviour approach." Internet Research 24 (2): 
246-66. https://doi.org/10.1108/IntR-11-2012-0243.

Rao, Siriginidi Subba. 2003. "Electronic books: a review and evaluation." Library Hi Tech 21 (1): 85-93. https://doi.org/https://doi.org/10.1108/07378830310467427.

Sirkeci, Ibrahim, dan Lóa Bára Magnúsdóttir. 2011. "Understanding illegal music downloading in the UK: A multi-attribute model." Journal of Research in $\begin{array}{llll}\text { Interactive } & \text { Marketing } & 5 & \text { (1): }\end{array}$ https://doi.org/10.1108/17505931111121543.

Stevans, Lonnie K., dan David N. Sessions. 2005. “An empirical investigation into the effect of music downloading on the consumer expenditure of recorded music: A time series approach." Journal of Consumer Policy 28 (3): 311-24. https://doi.org/10.1007/s10603-005-8645-y.

Swatman, Paula M.C., Cornelia Krueger, dan Kornelia Van Der Beek. 2006. "The changing digital content landscape: An evaluation of e-business model development in European online news and music." Internet Research 16 (1): 5380. https://doi.org/10.1108/10662240610642541.

Tewell, Eamon. 2010. "Resources for selecting popular music recordings." Collection Building 29 (1): 27-30. https://doi.org/10.1108/01604951011015277.

Vida, Irena, Mateja Kos Koklič, Monika Kukar-Kinney, dan Elfriede Penz. 2012. "Predicting consumer digital piracy behavior: The role of rationalization and perceived consequences." Journal of Research in Interactive Marketing 6 (4): 298-313. https://doi.org/10.1108/17505931211282418.

Walsh, Gianfranco, Tobias Frenzel, Klaus Peter Wiedmann, dan Vincent Wayne Mitchell. 2003. "Internet-induced changes in consumer music procurement behavior: A German perspective." Marketing Intelligence \& Planning 21 (5): 305-17. https://doi.org/10.1108/02634500310490256.

Wilcox, J. K. 2003. "Where have all the CD's gone.” Sound and Vision. 2003.

Williams, Peter, David Nicholas, dan Ian Rowlands. 2010. "The attitudes and behaviours of illegal downloaders." Aslib Proceedings: New Information Perspectives 62 (3): 283-301. https://doi.org/10.1108/00012531011046916. 


\section{Lampiran 1}

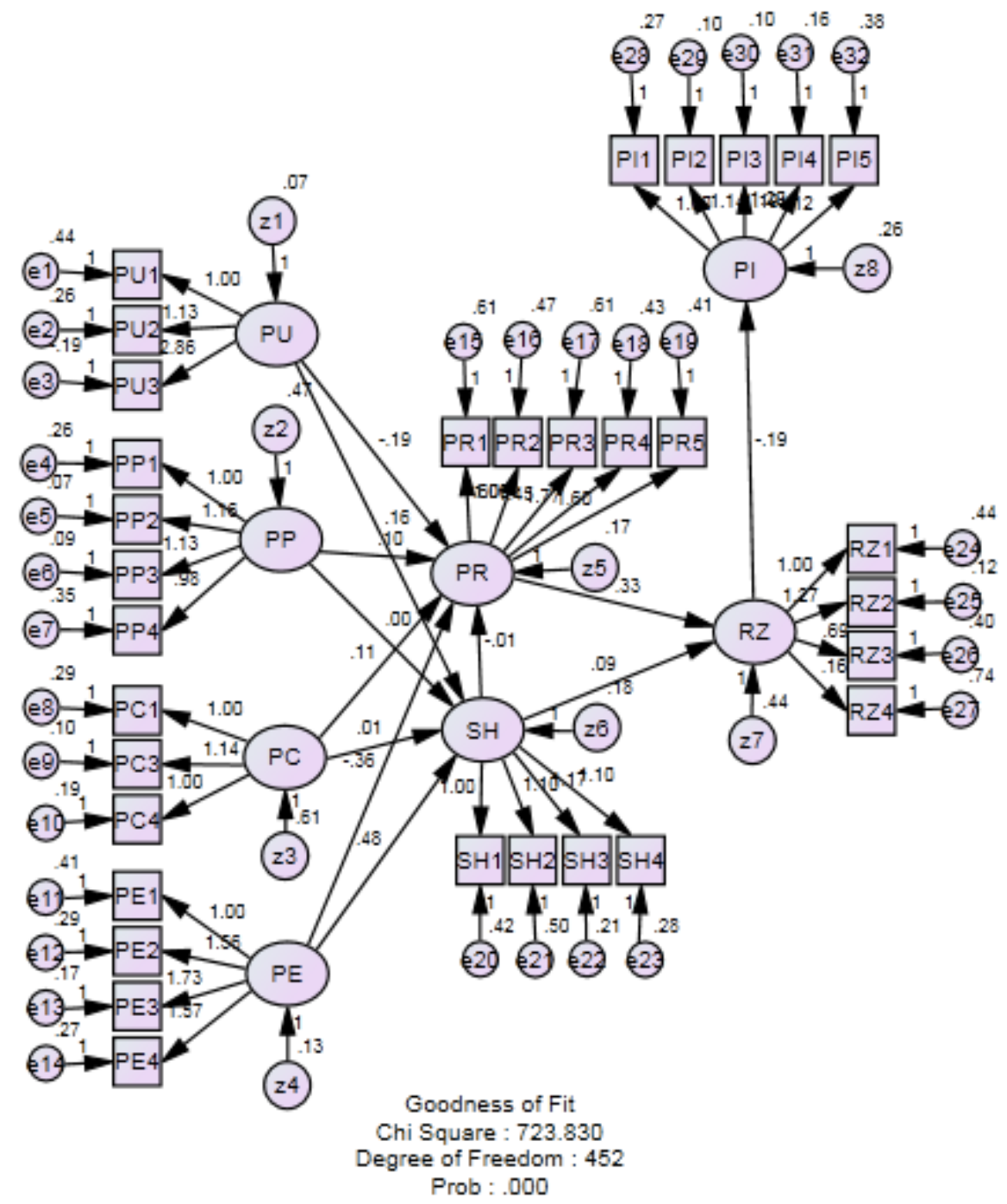

Gambar 3

Output AMOS 22 